\title{
The Innermost Enigmas of the Vedic Literature
}

\author{
[Finally Decrypted Successfully 5079 Years Since The Composition Of The Sacred Vedic Texts] \\ Milorad [sin Nade Tesla] Ivanković \\ Non-affiliated researcher \\ Vršac (Verschez) \\ i.kovic@yandex.com
}

\begin{abstract}
Ever since the Anglo-Welsh philologist William Jones introduced Sanskrit to the West two centuries ago, various western scholars have been trying relentlessly to decipher the ancient Vedic texts but with poor results. The inadequacy in their achievements is evident in the scholarly disputes that continuously take place between the fundamentally opposed schools engaged in the interpretation of Vedic texts. There are shortcomings in their methodology because the approach they rely on does not take into account the requirement of preserving authenticity in exploring the semantic relations among the Sanskrit words and phrases in the original Vedic texts. Against this background, this paper attempts to present a semantic approach to decoding Vedic texts, where prominence is accorded to faithful interpretation of the original Sanskrit words and phrases with an emphasis on preserving the accuracy of their contextual meanings. Further, the paper demonstrates how the innermost enigmas in Vedic texts are decrypted.
\end{abstract}

Key words: Betrothing, Confidentiality, Conspiracy, Unanimity, Soul, Bond

\section{Introduction}

The Veda is the oldest collection of religious texts of the Aryans and is regarded as a-pauruseya viz. "not composed by humans" but as divine revelation, hence it is still considered the most sacred writ by the people of India. Although the Veda in the past undoubtedly exerted a considerable influence on Hinduism the major religion of India, Vedism or authentic Vedic religion was very different from other branches of Indian religion. Consequently, the language and specific terminology of the Veda is hardly understandable not only to modern Indians, but equally to Westerners as well. NB. The astronomical configurations of the stars in the famous Vedic stellar saga about Prajāpati "Lord of progeny" (represented by the constellation the Mrga or Orion) who chased his daughter Ușas the Dawn (represented by Rohini the Aldebaran star) aligned exactly with Autumnal Equinox, and his subsequent pursuit by the god Rudra (called Tisya or Dhanuṣa the Archer represented by the star Sirius) aligned with the eve of the month of November on the Moon's path, allow us to estimate its dating precisely to the year 3059 BCE. This means that the antiquity of the Vedic hymns and prose texts delineating the saga at present day is exactly $\mathbf{5 0 7 9}$ years (cf. Ivankovic 2017).

While going through the attempts of decoding Vedic texts made by most of the western scholars of Sanskrit, it becomes clear that they have been prejudiced by the traditional views of their own religions.

Thus, E.W. Hopkins (1895) rejects the Vedic hymns as "trash" and "rather stupid hymns".

In the same vein, A.B. Keith (1925) claims that The 9th Book of the Rig Veda "hides no real depth of thought by merely puerile fancies".

A. Hillebrandt (1927/1980) sounds irritated in his words: "the bleak monotony of those (viz. Agni and Indra) hymns and their endless repetitions. If a careful examination of the sources shows that the one of the Vedic gods has essentially the same origin as several other and that what is new in him is merely the name and the individual coloring, we have no other way but to accept this and willingly put up with the dearth of ideas". And he explains 
accordingly "that the monotony of the gods in spite of the many names can be explained from the syncretic nature of Vedic mythology"(ibid.).

On the other hand, there are some promoting idealistic views about the Vedic texts. For example, P. Thieme (1973) sounds convinced that "Most striking feature of our picture" (viz. of some Vedic gods, esp. Varuna) is that "cosmic and moral functions are met with side by side in a way that suggest a monotheistic religion". Thieme has been maintaining that "by origin the gods are allegoric figures which later were taken seriously and through this process elevated to the rand of gods."

However, the most objective view expressed so far by any of the western explorers is the statement by Andrew Lang (1887) who has admitted candidly: "Nothing in all mythology is more difficult than to attempt to get a clear view of the gods of Vedic India."

\section{Two Diametrically Opposed Approaches to Vedic Exegesis}

There are two diametrically opposed schools or rather two irreconcilable approaches to the interpretation of the Vedic texts in the West:

A) naturalistic school of interpretation, that views gods as divinization of natural phenomena;

B) a new variety of interpretation called by Alfred Hillebrandt Begriffsmythologie in German language (from German Begriff "concept, idea, notion").

The differences between the two schools can be most clearly perceivable from Hillebrandt's Vedic Mythology (Vol.I 1927/1980 and Vol.II 1929/1980).

Hillebrandt says that he "would like to call it Begriffsmythologie since it regards abstract concepts or factors as the basis of the personification of the gods, or seeks the embodiments of abstract concepts directly in the gods of the Veda." Hillebrandt even complains that his "interpretation has provoked the criticism that he is under the influence of the naturalistic school of interpretation, in spite of his assurances to the contrary". Hillebrandt declares that "in any case, it has been far from his intention to turn this interpretation into a credo or an object of special worship" and added that "he has always adhered to the sources alone." According to him "the Vedic Indians liked to think in concrete terms, and the Rigvedic period was hardly favorable to philosophical contemplations." (Hillebrandt Vol.I, p.6).

Hillebrand has criticized his contemporary fellow Sanskritist Hermann Usener(1896) for his theory of the deification of abstract concepts in the Veda, arguing that "As in the case of Agni (the Sacred Fire) so also in Indra's (the thundergod) case these names (viz. their numerous epithets and attributes) are not Sondergötter (viz. Special or Abstract Gods) who merged with Indra at a later stage, but particularization of Indra's own character. This once amply demonstrates the untenability of Usener's in Indian context" (Hillebrandt Vol.II, p.133). He has also refuted the view of Hermann Güntert (1923) and his attempt to see different aspects of Gods of Law in Mitra, Varuna and Aryaman" (Hillebrandt Vol.I, p.5).

Although Hillebrandt admits that "there is no denying that the names of the gods derived from appellatives" he is quick to add that "they are merely 'derived'... but Indra, Mitra, Varuna lost their appellative basis long ago to such an extent that they cannot be recognized as appellatives any more, and appear in the Veda as firmly established personality and complete gods" and adds that "the etymological meaning is too general to say anything significant about the individuality of a god" (Hillebrandt Vol.I, p.6 and 7). A propos the Vedic god Varuna, F.B.J.Kuiper (1979) agrees with Hillebrandt, and asserts that "Varuna was a proper name (already in the Hittite-Mitanni treaty of ca.1380 BCE)". Kuiper considers Varuna as originally the god of the waters and of the netherworld, which becomes by means of shift (from the lower divine realm of the Asuras or demons, to the upper divine realm of the Devas or gods) occurring at night the sky in its nocturnal aspect. 
The German born Harvard professor M.Witzel (1984) in his contribution to this naturalistic approach of Kuiper, adds that "Varuna's home in or at the Milky Way moves from a rising point in the east, counter-clockwise around the North Pole and sets in the west. The heavenly river of the night (the northern "ocean" samudra of the Atvarva Veda XI 2.25) flows into the western one of the two oceans surrounding the earth and becomes the netherworld river in day time." Incidentally, Kuiper has adopted the designation "Binder" for Vedic Varuna proposed earlier by the French scholar George Dumézil (1948/1988) who has identified Varuna with the Greek god Ouranós the Sky/Heaven.

There are however, more numerous modern scholars who advocate the same view like Usener and Güntert, while look for purely Christian ideas and concepts in the Vedic texts (viz. gods as personifications of abstract concepts) like Paul Thieme (1973, who even cites the Old Testament Proverbs in support to his theory on Varuna), an epigone of the Frenchman Antoine Meillet who proposed to explain the Indo-Iranian god Mitra/Mithra as "god Contract" and Varuna as "god Law/Order" (Journal Asiatique 10, 1907, pp.143 ff.). Meillet's idea was taken also up and applied to god Varuna by Heinrich Lüders (1951) who posited Varuna as "god Oath". Thieme followed both Meillet and Lüders, but proposed a more general and comprehensive appellative meaning for Varuna, viz. "god True Speech, Spoken Truth, Verity". More recently J.P.Brereton (1981) has modified slightly Thieme's rendering of Mitra, Varuna and Aryaman as "gods Contract, Verity, and Hospitality" by proposing not-so-different but rather quite similar substitutes for them, viz. "gods of Alliance, Commandment, and Civility (or Customs)".

But Hillebrand has warned researchers that "we should not read the later developments into the Rig Veda now just as one did formerly look for Indo-European or even Christian ideas in the Rig Veda" (Hillebrandt Vol.I, p.12). As for Varuna in particular, Hillebrandt (Vol.II, p.22) states categorically: "No explanation of Varuna should be considered adequate which does not do justice to the Rig Veda, to the ritual and to classic Sanskrit, and which does not explain the connection between the three conceptions (sc. of his character)". He further clarifies his standpoint: "I do not assert that Varuna was familiar to the Indians themselves as the Moon god; I maintain simply that all his later characters can be readily explained only from the prehistoric character of his (sc. As the Moon).” (Hillebrandt Vol.II, p.32).

With regard to the deification of the abstract concepts, Hillebrandt has keenly noticed that "the Begriffsmythologie cannot explain why and when so many naturalistic elements came to be associated with abstract concepts and why these took naturalistic forms after their semi-philosophical beginnings" (Hillebrandt Vol.I, p.3-6). He also maintains that "we are not primitives...we have therefore no right to correct this conception (viz. of the ancients) or to read our own sentimental lunar lyricism into the texts" (Hillebrandt Vol.I, p.10).

Hillebrandt adds in a somewhat appeasing tone "It is of course understandable if the modern exegete wishes that the Vedic heavens were more plentiful than they actually are...nothing would be more gratifying than to rediscover the reflected splendor of Indian life in the Indian sky or to heighten the content of its life with abstract deities. The main thing, however, is that we should also be able to adduce evidence from the Vedic literature" (Hillebrandt Vol.II, p.32).

After the period of enthusiastic attempts to interpret Vedic gods as abstract concepts, the trend recently has somewhat changed again in favor of naturalistic approach to Vedic religion. Thus Georg von Simson (1997) has advanced the theory of Mitra and Varuna as the morning star and the evening star. And more recently, Catalin Anghelina (2013, 2014) has re-discovered in fact an old view of the main Vedic gods as the constellations of the zodiac along the ecliptic. Thus she has been actually only guessing that Varuna, Mitra, Aryaman, and Indra authentically represented the constellations and stars, viz. Aquarius, Aldebaran star (in the constellation Taurus), Regulus star (in the constellation Leo), and the constellation Taurus, in this order, respectively. However, one year later Anghelina has proposed a newly defined guess-order for the same deities, viz. Varuna=Aquarius, Mitra=Pisces, Aryaman=Aries, and Indra=Taurus .

The western scholars seem to read into the Vedic texts their own wishes and expectations (mostly irreconcilable with one another) of what the Vedic religion should mean to them and not that what it authentically was to mean to the ancient Vedic seers and the devotees of the Vedic gods during Vedic Age when Vedism was a living force among the Aryan society. 


\section{Gods are Desireful of Cryptography}

Every explorer of the Veda must always bear in mind that paró 'kșakāmā hí devăh "Gods are desireful of cryptography" (Śatapatha Brāhmaṇa VI 1.1.2 and 11) or paró 'kṣapriyā iva hi devấh viz. "(Vedic) gods are fond of cryptography, viz. of cryptic language, viz. of the meanings hidden from the eyes [=parah akșa, literally "beyond the eyesight"] of the common people" (Śatapatha Brāhmaṇa XIV 6.11.2; Aitareya Brāhmaṇa III 33.6 and VII 30.4; Taittirīya Brāhmaṇa I 5.9.2; Aitareya Upanișad I 3.14). Thus the Veda seems to be indeed a very hard walnut to break it up and open to the eyesight of those uninstructed into the authentic terminology of the Veda.

\section{The Non-Existence of Intellectual Property Law}

In the Vedic Era there was no intellectual property law which had to protect the inventions of the Brahmans. Therefore, the priesthood had to secure their business, viz. the means of production (that is their intellectual achievements, or in plain words their "sacred" terminology) by keeping their utilization enigmatic and cryptic, viz. unintelligible to the outsiders and to non-members of their own guild.

And indeed, their achievements are still deserving the highest esteem even today, for the modern especially western scholars and "experts" of various scientific disciplines in spite of having at their disposal all the knowledge of the world coupled with ultraspeed supercomputers are not yet capable of deciphering successfully the sacred Vedic texts composed and encoded cryptically in such a far remoted antiquity of more than five thousand years by the ancient Vedans, who did not even write it down on paper or tablets, but preserved it solely and exclusively by memory instead. This proves the thesis that modern times and advanced technology can add actually nothing to the intellectual capability of the human species.

\section{A Razor-Sharp Precision of the Vedic Definitions}

Every observation of the ancient Vedic seers and consequently every definition of religious and philosophical concept had been done by razor-sharp precision. In fact, the ancient Vedic seers used to supplicate God Pūṣan: sam nah sissíh $i$ bhurijor iva "sharpen us (sc. mentally, intellectually) like a razor in the skilled hands (sc. of a barber)" (Rig-Veda VIII 4.16). Thus modern exegetes should not strive to "invent" their own new meanings and significance of the Vedic divine characters but only to follow the authentic terminology and words of the Veda as they were conceived by the incomparable grand Vedic seers. It is particularly harmful to any objective analysis of the Veda when one resorts to reloading of the authentic content of the texts themselves. Therefore, the scientific task of the modern explorers should be to detect authentic unaltered meanings of the Veda unbiased by prejudices filled with other concurrent religious conceptions and seemingly more correct views and theories of modern science.

\section{Veda as Ancient Brahmanic University Curriculum}

Modern western scholars entertain themselves with a weird nonsensical idea that only the hymns of the Rig Veda represent the authentic Vedic religion, whereas other Vedic texts are just later misconceptions, contaminations, and exaggerations added by the new generations of seers which no longer had the proper insights into the original Vedic doctrines. To make a comparison, arguing that only the hymns of the Rig Veda are authentic remnants of Vedic religion, would be the same with saying that only the Book of Psalms from the Old Testament represents authentic Jewish religion, which is a totally absurd view. In point of fact, there is a strict gradation within the corpus of the Vedic texts into four levels of learning:

1. Samhitās the collections of hymns and eulogies in verse and in prose

2. Brähmanas the instruction manuals for proper performance of the rituals

3. Aranyakas the forest texts dedicated to recluse individuals who seek to find the correlations between religious rituals and philosophy 
4. Upanișads or Gühyas the secret doctrines dedicated to those who have completely abandoned the performance of religious rituals for the sake of purely philosophical attitude toward the world and phenomena.

These four levels of learning correspond to and stand in strict correlations with the four stages of development or áśramas of a human individual during one's lifetime:

1. Brahma-ācārya a young celibate Student of the Veda who follows Brahman the religious teacher in learning (how to pronounce properly, recite publicly and compose) the sacred hymns

2. Grha-pati Householder or Lord of the House a married man who is instructed how to perform the sacred rites in his own house

3. Vana-prastha the Forest Dweller a recluse who has abandoned society for the life in nature to devote himself to religious meditation and the attainment of philosophical insights

4. Samnyāsin a Renunciate, an ascetic who has renounced all the worldly affairs and devoted himself completely to meditation on and realization of the supreme principle.

Thus, the collections of sacred hymns for celebrating various divine names are on the level of elementary education curriculum, the other three corresponding to High School, University and Post-Graduate Scientific Degree of learning, respectively. Consequently, it cannot provide a proper insight into the authentic concepts of Vedic religion, how much less into the secret doctrines of the $3^{\text {rd }}$ and $4^{\text {th }}$ degree of learning.

Subsequently, there follows the only valid conclusion: any explorer who is inclined to engage oneself properly in Vedic exegesis should first learn the Whole Veda thoroughly and not just the hymns, viz. Psalms devoted to celebrating the godhead.

The attempts at proper decrypting of the authentic concepts of the Vedic gods, and especially that of Varuna, has been defined as "a forbidding task" (Brereton 1981). Sooth to say, neither Brereton nor any other explorer in the west has not yet fulfilled the task successfully and satisfactorily.

\section{The Authentic Vedic Views on the Vedic Gods}

The real character of the Vedic god Varuna has been for almost three centuries the most controversial subject of Sanskrit and Vedic studies in the west. Though it seems to be an unsolvable enigma, it can be deciphered properly and successfully under the condition that one follows exactly the instructions and explanations given by the Vedic scriptures and does not intrude one's own "inventions" into the process of exegesis. The present treatise follows precisely the authentic words and explanations of the Vedic texts unbiased by the author's intrusion or contamination of any kind into their original content.

\section{The Knot}

The Vedic god Varuṇa is symbolically represented by the granthi viz. "Knot" (Śatapatha Brāhmaṇa I 3.1.16), and is said that krṣnam vāso viz. "a Black Cloth" is the fee to be given to the officiating priest for the oblation offered to Varuna; since tad(d)hi vārunam yat krșnam "what is Black belongs indeed to Varuṇa"; or any kind of Cloth will do if the Black one is not available, because vāsah syād granthibhir hi vāso vārunam varunyo hi granthih viz. "by reason of its Knots indeed that the Cloth belongs to Varuṇa, for the Knot is sacred to Varuṇa indeed" (Śatapatha Brāhmaṇa V 2.5.17).

The term granthi "Knot" is derived from the verb grath variant granth "to tie, bind, fasten, string together". In fact, the fundamental function of Varuna is indicated by a verb fully synonymous with granth, viz. the verb bandh "to bind". (cf. also Kuiper 1979, p.73), in addition to the verb grah (variant grabh) "to seize, grasp, lay hold of, catch, imprison, capture" (analogous to binding), hence the sinners and sick persons alike, are said to be Varuna-grhita 
"seized by Varuṇa". In accordance with his fundamental function, various aquatic creatures called grāha "seizers" (viz. crocodiles, sharks, serpents, alligators, etc.) and makara "crocodile-like monster", along with the nāgās "dragons" and sarpas "serpents" are assigned to Varuna whose abode is the samudra "ocean/ sea". Of the aquatic animals only those called nakra "crocodile" are sacrificed to Varuna (Hillebrandt Vol.I, p.295). In Hindu mythology makara (and sometimes nakra) is considered to be the vehicle on which Varuna rides holding pāśa the "noose" in his hands.

Thus, from the verb granth being synonymous with bandh "to bind", it comes quite logically that the term granthi "Knot" must be synonymous with bandha the "Bond", and fully applicable to all Varuna's aspects or functions. This should not be considered a passing fancy of the Vedic ritualists as western scholars use to think, but it is the real and true nature of Varuna, as the following examples indisputably testify.

In the famous hymn "Wedding of the Daughter of the Sun" Rig-Veda X 85.24 Varuna is used exactly in this sense: pra tvā muncāmi varunasya pāśäd viz. "I release thee (viz. the bride) from the noose of the Bond (sc. of "betrothing" or "affiance") by which the bride is bonded before marriage. There are quite analogous usages of the same term in Anglo-Saxon, e.g. the term "knot" denotes "a unifying Bond, especially a Marriage Bond". Besides, there is an idiom "My word is my Bond" used to say that one always keeps one's promises. And Betrothing or Affiance is founded on one's promise in engaging oneself to marry (viz. to plight one's troth, to bind oneself to someone in marriage).

"The appearance of the Atharva Veda (though long unrecognized as canonical text), the content of which is not younger than that of the Rig Veda in all cases, means in itself a great enlargement of the original area of belief" (Hillebrandt Vol.I, p.16).

In the Atharva-Veda IV 16. 2 Varuna again is used in this sense of Bond; dvau samnișadya yan mantrayete rāja tad veda varunas trtīyah viz. "When two sitting together speak (talk, whisper, counsel in secret) King Varuna knows that as the Third"; the verse clearly presents the concept of Varuna as the "Bond", viz. the Bond of Confidentiality (=secrecy, discretion, privacy), even the Bond of Conspiracy (from con + spire $=$ to breath together secretly), or at least the Bond of Unanimity (from un + animous $=$ of one soul, spirit, mind). Moreover, from there it becomes perfectly clear how the related Avestan term uruuan (a noun of the nasal-ending class, in the Nominative uruuā) has developed in Iran a secondary meaning "soul, spirit". The soul functions exactly as the "Bond" in the body for it keeps one's corporeal integrity as long as it presides within; since after the soul leaves the body, viz. when one's soul passes away, the body is inevitably subject to decay. What is significant, in the Hittite-Mitanni treaty of ca.1380 BCE (cf. Founert 2010) the name of the Aryan god is recorded in the form U-ru-ua-na (viz. dual of the Avestan-Iranian form uruuan) instead of the Indo-Aryan Varuna.

NB. The difference between $-a$ stem (Varuna) vs. $-n$ stem (Uruuan) is nothing unusual in ancient language usage for there is quite identical case in the Rig Veda whereby the name of the God Püșan is attested in both variants, e.g. Püșan as well as Pūṣana (e.g. Rig Veda X 5.5 Pūṣanasya; Rig Veda X 93.4 Pūṣaṇo bhagah̆).

\section{The Four Types of Bonds}

Atharva-Veda IV 16.8 even makes the distinction between four types of Varuna as legal terms (according to Lüders this verse is an admonition given by the judge to the one who is about to take an oath in order to bear witness, cf. Lüders Vol.I, p.39), but also between two opposite forms divine and human as well: yáh samāmyò3 váruno yó vyāmyò 3 yáh samdeśyò 3 váruṇo yó videśyò y yó daivó váruno yáś ca mấnuṣah viz. "The Bond (=Varuṇa) that is sam$\bar{a} m y \grave{a}$, the Bond that is vy-ammyà, the Bond that is samdeśyà, the Bond that is videśyà, the Bond that is the divine (viz. of the gods, = natural), the Bond that is the human (viz. of the men, = social)."

NB. There are two erroneous readings in the Sanskrit version of this verse of the Atharva Veda retrieved at TITUS (http://titus.uni-frankfurt.de/texte/etcs/ind/aind/ved/av/avs/avs.htm), viz. it reads erroneously samābhyò3 instead of the correct samāmyò 3 , and erroneously vyābhyò 3 instead of the correct vyāmyò 3 . 
Those four legal terms have been further elucidated by Hoffmann (KZ 83, 1969) in German as follows: a) samämyà related to sam-āmá "Vertragseid" (= contract made under mutual oaths); b) vy-āmyà related to vy-āmá "Abschwörung" (= recantation, disavowal, abjuration); c) samdeśyà "zu einer magischer Zuweisung gehörig" (= related to allocation, allotment, assignment), d) videśyà "zu einer magischer Abweisung gehörig" (= related to refusal, denial, repudiation). In addition, Ingrid Eichner-Kühn (MSS 41, 1982) has found more examples (from the Taittirīya and Maitrāyanī Saṃhitās and the Rigveda as well) that confirm the basic meaning "to swear" of the Vedic root $A M$, e.g.: "TS amīṣva 'schwöre! (=swear! Ipv.)', āmīt 'schwor' (=vow, oath), TS sám amāte 'die beiden schlossen einen Vertrag' (=to conclude a contract by mutual oaths), MS + sám-ānta- 'das gemeinsam Beschworene'(=sworn together, Past Participle), RV *ānta- 'geschworen'(=sworn) in āntaka-drúh- 'gegen eine eidliche Abmachung trügend' (=the one who is deceptive to an agreement already sworn). Naturally the possessive compound $\bar{a} \operatorname{ta} a+k a$ is derived from $\bar{a} m+t a=$ Past Participle the root $A M+k a$ (a secondary nominal suffix often used to form adjectives with the possessive sense).

Thus, evidently, the four types of Varuna expounded above are undoubtedly conceived as social or ethical "Bonds". This is corroborated by the very next verse of the same hymn, Atharva Veda IV 16.9: taís tvā sárvair abhi syāmi

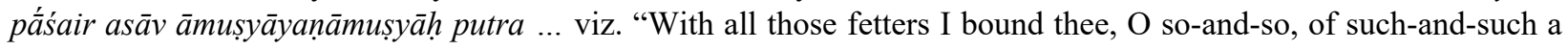
family, son of such-and-such a mother..."

\section{God as a Drop}

However, the same appellative term is applied not only to the social aspects of the concept of Bond but equally to its natural aspects as well, as is demonstrated by a previous line 3 of the same hymn. Thus in the Atharva-Veda IV 16.3 Varuna the "Bond" is depicted naturalistically devoid of his social aspects: utéyám bhümir várunasya rấjña utấsaú dyaúr brhatî́ dūré antā utó samudraú várunasya kukșî́ utấsmínn álpa udaké nílīnah viz. "Both this earth is King Varuna's and yonder high heaven with remote ends is his; the two oceans are Varuna's loins; in this small (amount of) water is he hidden."

Naturally, the phrase alpa udaka "small water" is synonymous with indu viz. "a drop (of water)" and bindu "a drop, globule, dot, spot, detached particle", but also with drapsa viz. "a drop" an epithet assigned to gods Soma (Rig Veda IX 78.4, etc.) and Varuna (Rig Veda VII 87.6) alike. Both (b)indu and drapsá visually represent a small spherical mass or globe of liquid or something, hence being evocative and imitative of "knot" or "bond" (as above of water) which represents Varuna. Both the terms likewise designate Soma the Moon who is "a few times mystically identified with Varuna" (Macdonell 1897, p.110). Besides, it is specified that mitró 'har ájanayad váruno rátrim "Mitra produces the day, Varuna produces the night" (Taittirīya Samhitā VI 4.8.3) and that maitrám vấ áhaḥ vāruṇ̂́ rấtrih viz. "the day belongs to Mitra, the Night to Varuna" (Taittirīya Brāhmaṇa I 7.10.1). This is related to the next section because "the Moon is the Lord of Winter" (Hillebrandt Vol.II, p.124).

\section{The Bond of Winter}

The ritual texts emphasize another specifically natural aspect of Varuna, for they identify him with Winter: $\underline{\text { hemantó }} \underline{\text { í }}$ várunas viz. "Winter indeed is Varuṇa" (Maitrāyanī Sạ̣hitā I 10.12 and Kāṭhaka Saṃhitā 36.6). What is more, Varuna in his true and awe-inspiring form is depicted as "a whitish, baldheaded man with oversized protruding teeth (viz. bucktoothed), and yellow eyes”, cf. váruno vaí jumbakáh sākșádeva várunamávayajate śuklásya khalatérviklidhasya pingākssásya mūrdháni juhotyetadvai váruṇasya rūpám rūpénaiva váruṇamávayajate (Taittirīya Brāhmaṇa III 9.3.15 and Śatapatha Brāhmana XIII 3.6.5), the description which is perfectly congruent with Winter season.

There are so many vivid descriptions of winter particularly from Germanic literature which actually circumscribe the very nature of Winter Season as the "Bond". Note especially the utilization of the verb bind (with various prefixes) and the appellative bond(s) in this context, e.g.: 
a) Beowulf 11.1133-34: winter yde beleac îs ge-binde "winter locked the waves in its icy bond"; b) Beowulf 1.1608 ff.: îse gelicost thonne ferstes bend onloeted "loosens the bonds of frost"; c) Andreas 1258: snâw eordan band winter gewopum the snow bound the earth with the snow-drifts of winter" d) Denksprüche II 76: ân sceal in-bindan forstes fetre "may un-bind the fetters of frost"; e) Seefahrer 32: hrim hrúsan band "the hoar frost bound the earth"; f) Grimm, Deutsche Mythologie, p.634: die Heide liegt in Banden des Winters "the hearth lies in the bonds of winter" ; g) Grimm, Nachträge III 231: der Winter bannt die Heide "the winter binds the hearth"; h) Andreas Aabel: Nys brod den vintrens bând "not long ago it broke through the bonds of winter".

All the examples have been collected by Hillebrandt (Vol.II, p.110-111) in order to support his theory on Vedic character Vrtra as the demon of Winter, and not in relation to Varuna himself.

Contrary to Hillebrandt's view, the preceding examples make it perfectly clear why is it Varuna the "Bond" identified with Winter and its very attributes "the fetters (sc. of ice and frost)", for it keeps the nature "bonded" (viz. in "bondage") during winter season. But Hillebrandt (Vol.II, p.27) has fiercely denied the validity of the above equation maintaining: "If Varuna were Winter, Mitra ought to be Summer to assume which there is no ground". This contradicts his own statement (Hillebrandt Vol.II, p.22) that "Mitra and Indra are mythological synonyms, although there is a difference in the evolution of their concepts". Moreover, Śatapatha Brāhmaṇa III 2.4.18 adds categorically: syādetadvắ avarunyam yán maitram "that which is of Mitra is not of Varuna". Since Varuna is Winter, Mitra naturally cannot but designate Summer.

Mitra is indisputably related to Summer, since the Avestan Mithra is positioned in Iranian calendar as divinity of the midsummer viz. seventh month of the year, since "Mitra was connected with the middle of the year already in IndoIranian" (Schmidt, 1978, p. 378), in Avestan called Mi rahe and Mehr Mah and Mehr Rouz in modern Persian (Nabarz 2005: 160). Thus Avestan Mithra undoubtedly shares the same characteristics with Vedic Indra. As Hillebrandt already noticed: "The summer signifies the height of the sun god's reign and the Brāhmanas often assign the summer to Indra" (Hillebrandt Vol.II, p.126). This is confirmed by Maitrāyanī Samhitā II 7.20. "Hence also the occasional remark grīṣme vấ indro vrotrám ahan viz. "Indra verily killed Vṛtra in summer" (Hillebrandt Vol.II, p.347, note 171), attested again by Maitrāyanī Samhitā I 6.9. But neither interpretations of Mitra as "contract" by Meillet's (1907) nor Mitra as "alliance" by Brereton (1981) cannot explain Mitra's association with Summer season.

The innate connection of Mitra with the summer is fairly detectable only from the genetic (viz. etymological) relationship between Vedic appellative mitra and Slavic mirb "peace", with some subtle shades in meaning, viz. "stillness, motionlessness, standstill" which undoubtedly associates Mitra with summer solstice, since sol + stitium designates exactly "the standstill of the Sun". Moreover, Indra bears the title mitra-pati "Lord of peace/standstill" for he too is associated with summer solstice. In the Avestan Yasht No. 10 (verses 95-96, cf. also Gershevitch 1959), Mithra is depicted as holding the vazra viz. "thunderbolt" in his hands (related to Vedic vajra "ibid.") the weapon otherwise exclusively attributed to the Vedic thunder-god Indra. What is more, Avestan Mithra in the same hymn (verses 70-71) is associated with VarəArayna the Avestan counterpart of the Vedic Vrtrahan "Vrtra-killer" the epithet of Indra.

Hillebrandt himself has gone frequently past the truth (viz. that Varuna is actually the "Bond" in both Natural/Concrete as well as Social[=Ethical]/Abstract sense) so closely that he would certainly resolve the enigma if it were not for his stubborn refutation of Varuna's identity with winter, treating this identification as an occasional fancy of the Yājñikas (viz. "Ritualists"). He then goes to expound his viewpoint in wide terms, maintaining that "The identification of Varuna with Winter as given here (viz. in Maitrāyanī Saṃhitā I 10.12 and Kāṭhaka Saṃhitā 36.6) does not occur anywhere else and it is not necessary either. Elsewhere the seasons are distributed differently. For instance, Autumn is assigned to Mitra-Varuna" (Hillebrandt Vol.II, p.20). The assignment of Autumn to both Mitra-Varuna in dual number actually confirms their individual identification with Summer and Winter, respectively. Modern Sanskritists and linguists agree that there is a genetic relationship between Vedic appellative mitrá and Slavic mirz "peace" (Mayrhofer 1976, p.634; Ježić 1994). What is significant, the Slavic term mirr besides "peace" has several other very important nuances in 
meaning, viz. "tranquility, quietude, silence", which most appropriately designate natural aspects of the Vedic mitrá. Thus after the Summer Solstice Vedic god Mitra due to the course of time gradually withdraws from summer season stepping slowly into Autumn the season of Quietude (peace, tranquility) when the days begin to shorten and nights get prolonged, and gets closer and closer to his partner Varuna (of the Vedic dyad of complementary opposites) to meet him in late Autumn, introducing colder and colder days and night till the "Bond of Winter" finally takes firm grasp on the whole nature (in the Dead of Winter).

Nonetheless, Hillebrandt seems to have had a second thought while he admitted: "But an argument in its favor is the employment of yava (=barley) which is used otherwise in sacrifices for Varuna. Thus yava is cereal that ripens in Winter. It is probable that the Varunapraghāsa, performed for the release from the fetters of Varuna, served at first the same purpose as the concluding rites of Agnistoma, namely, the release of Varuna's fetters at the end of Winter" (Hillebrandt Vol.II, p.21). "We have seen earlier that Black animals are dedicated to Varuna and White ones to Mitra. (And whatever is well-offered in sacrifice belongs to Mitra and whatever is ill-offered to Varuna). Now one cannot fail to see that also the fetters of Varuna from which one is released, are conceived as the opposite of jyotih, of light and immortality and that the release from the fetters is akin to the liberation from tamas (=darkness, death). When we recall that the annual Agnistoma can be regarded as the spring sacrifice, then it would appear that the antithesis in which Varuna" fetters are contrasted here with suvar (=svar "sun[shine]") and jyotih ("light, brightness") rest on a natural cause. (Hillebrandt Vol.II, p.18).

In the Note 98 (Vol.II, p.297) Hillebrandt keenly observes: That "Varuna's fetter" is thrown into water proves nothing in favor of the rainy season. This recalls the rites performed in spring for driving the Death away, when a figure or a doll which represents the Death is thrown usually into water."

Another Hillebrandts's remark is worthy to mention in this context: "Mitra-Varuna are often associated with cattle... This is to de with the sacrifice of a barren cow...This custom of concluding the spring sacrifice with the offering of a barren cow for Mitra-Varuna or this custom is appended to the spring festival that celebrates the end of winter is a reminiscence of the just-concluded winter. In a tropical climate a barren cow is not quite appropriate for the spring sacrifice; it would be a symbol rather of Winter of the barren period, and would well accord with the antithesis between tamas (=darkness) and jyotir or svar (=light), an antithesis that is expressed so clearly at the conclusion of the Agnistoma" (Vol.II, p.18, 19).

As for color Black, the fundamental designation of Varuna, it represents naturally the "Bond" of all colors, for it actually comes as the result of bondage (viz. absorption) of all visible spectrum light-waves by a surface of an object incapable of reflecting (viz. mirroring) the light into its environment. Thus, again, Varuna the "Bond" is the most natural, most objective and most appropriate designation of a divine entity associated with Darkness, Night, Destruction, Winter the barren period, Death, Realm of the Invisible (viz. Netherworld, the Realm of the Dead), of which color Black is symbolic.

Moreover, Varuna is explicitly identified with Death mrtyur vai varunas "Death indeed is Varuna", and is even equated to pāpman "evil" (Kāṭhaka Samhitā XIII. 2), just like Vedic demon Vrtra (Śatapatha Brāhmaṇa XI 1.5.7). This semblance of Varuna and Vrtra has led some scholars (e.g. Bergaigne 1883, Coomaraswamy 1935, Eliade 1978, Sutherland 1991) to identify the sovereign god Varuna with the serpentine demon Vrtra himself. Based on the references assembled by Coomaraswamy, Eliade has taken virtually the same standpoint: "It is to be noted that his [viz. Varuna's] mode of being - terrible sovereign, magician and master of bonds - admits of a surprising closeness to the dragon Vrrtra... What is more, Varuna is assimilated to the serpent Ahi and to Vṛtra" (Eliade 1978, p.202-203). Sutherland also maintains: "His [sc. Varuna's] punishing, judgmental side is thought to be responsible both for the constriction or "binding" of humans in the bonds ( $p \bar{a} s a)$ of sin and for withholding or "binding" of the waters. In this sense, he has been assimilated to the primordial Vedic asura Vrtra, the supreme serpentine power imprisoning the waters" (Sutherland 1991). 
Kuiper while objecting to Bergaigne's view, argues: "Bergaigne, who rightly stated that there was a mythological relationship between Varuna and Vrrtra, was wrong in identifying them directly". Kuiper has correctly observed, that "the demon Vrrtra is killed, but Varuna is incorporated in the group of Devas" (Kuiper 1979, p.34). Naturally, as the guardian of rta viz. (natural and social) world order. Kuiper also maintains that "To Varuna, the ancient god of the waters of Chaos, a new function is now assigned as the guardian of the cosmic law (rtá-)...As a result of this process of differentiation, the undifferentiated Chaos now constitutes itself as a nether world in opposition to the upper world" (Kuiper 1960, p.219). It seems therefore, that there is indeed some argument to speak in favor of the equation Varuna = Vrrtra, since the ritual texts expressly identify Vrrtra with Soma vrtro vai sóma "Vrrtra verily is Soma" (Śatapatha Brāhmana I 6.4.18; IV 1.4.8; IV 2.5.15; IV 4.3.4), sómo vaí vrótráh "Soma verily is Vṛtra" (Maitrāyanī Samhitā III 7.8), and Soma with the Moon sómo vaí candrámās "Soma verily is the Moon" (Maitrāyanī Samhitā II 1.5).

This and other common attributes of Soma and Varuna have seemed convincing enough for Hillebrandt to conclude: "Neither a god of night nor a god of winter can account for all the qualities that found expression in Varuna. Varuna as the Moon god alone can do justice to all the attributes" (Hillebrandt Vol.II, p.35). On this point Hillebrandt elucidates his standpoint more clearly: "I do not assert that Varuna was familiar to the Indians as the Moon god; I maintain simply that all his later characters can be readily explained from his prehistoric character of his (viz. the moon)" (Hillebrandt Vol.II, p.32).

\section{Nocturnal Aspects of the Bond}

And indeed Varuna has not been traditionally viewed as the Moon but rather as nocturnal aspect of the Sun, e.g. Kauśîtaki Brāhmana XVIII 9: yó ásau tápati ...ástam yanta... sá vā eṣo apáh praviśya váruṇo bhávati viz. "He who gives heat [viz. the Sun] ... at the setting [sc. in the evening] ...having entered the waters becomes Varuna". Varuna too appears as one of 108 holy names of the Sun in the Mahābhārata III 3.24. And more, the Vedic dyad Mitra-Varuna are equated to two different aspects of the Sun by Atharva-Veda XIII 3.13 the Glorification of Rohita viz. the "Red One" (viz. the Sun) which specifies explicitly: sá várunah sāyám agnír bhavati sá mitró bhavati prātár udyán viz. "At evening he (=Rohita) becomes Varuna (invisible, nocturnal Sun), viz. Agni (the Holy Sacrificial Fire, for the sacrificial fires do not shine at night, but are fanned first in the morn), ascending in the morning he becomes Mitra (visible, diurnal Sun)." And the Rig Veda itself declares categorically: indram mitrám várunam agním āhur átho divyáh sá suparnó garútmān ékam sád víprā bahudhá vadanty agním yamám mātariśvānam āhuh viz. "they call him Indra, Mitra, Varuna, Agni, and also Heavenly Fair-Winged Garutmat (viz. Devourer Bird = Heavenly Fire the Sun), that which is One and only Existent ecstatic poets call by many names, they call it Agni, Yama, Mātariśvan." (Rig Veda I 164.46).

The Maitrī (or Maitrayanīya) Upanișad VI 14 explicitly states that the Bright half of the Year (when the Sun moves northward) is Ägneya "of Agni/the Fire", whereas the Dark half of the Year is Vārunam "of Varuna" (the period of the year when the Sun moves southward, viewing to the right of an spectator facing east, hence called daksinayana $<$ dakșina "right > south", which is the path of the deceased ancestors or pitryanna associated with the yearly period of darkness (viz. prolonged nights). Moreover, the next sentence of the Upanisad specifies that "in its southward course (viz. Dark Half of the Year) from asterism Sarpa (the Serpent) to half of Śravistha (the Drum) is called Saumyam "of Soma, viz. of the Moon". NB. [Note again here Varuna's proverbial connection with Serpents]. Thus, Varuna paradoxically is identified with Soma the Moon as the ruler of the Dark half of the Year, though traditionally he is rather viewed as a specific aspect of the Sun (as above Rig-Veda I 164.46, Atharva Veda XIII 3.13).

\section{The Honey of the Gods}

Consequently, Bergaigne (1878) seems to be perfectly right when he observed: "Nevertheless the identification of Soma with the Moon does not exclude his identification with the Sun" in spite of Hillebrandt's refutation of this possibility when he remarks: "I cannot abstain from pointing out the improbability of Bergaigne's thesis that a single 
name of a god has so many meanings (viz. Moon, Sun, lightning)" (Hillebrandt Vol.I, p.186). This is confirmed by the Philosophical texts of the Upanișads, for the Chandogya Upanișad III 2.1 declares explicitly: asau va a aditya devamadhu viz. "Yonder Sun, verily is the Honey of the gods". Thus though is Soma invariably identified with the Moon by the ritual Brāhmana texts, in fact it is not the dead planet-object moon which serves as the drink and food of the gods (it is only a chalice in which nectar is collected), but the ambrosia (viz. nectar of immortality) in the moon is actually the light he receives and accumulates from the Sun (for the moon has no light of his own). This is the work of $m \bar{a} y \bar{a}$ originally the power of "change" in nature ascribed especially to Varuna, which later acquired the meaning of "magic power" and even "illusion". Because what common people see as such it is not in reality.

Accordingly speaks Aitareya Brāhmaṇa III 44. 6-9: sa vā eșa na kadā canāstam eti nodeti (=na udeti) tam yad astam etīti manyante, 'hna eva tad antam itvāthātmānam viparyasyate, atha yad enam prātar udetīti manyante, rātrer eva tad antam itvāthātmānam viparyasyate, 'har evāvastāt kurute rātrīm parastāt sa vā eșa na kadā cana nimrocati na ha vai kadā cana nimrocaty, etasya ha sāyujyam sarūpatām salokatām aśnute ya evam veda ya evam veda viz. "The Sun does never set nor rise. When people think the sun is setting (it is not so in reality). For, after having arrived at the end of the day, it makes itself produce two opposite effects, making night to what is below and day to what is on the other side. When they believe it rises in the morning (this supposed rising is thus to be accounted for). Having reached the end of the night, it makes itself produce two opposite effects, making day to what is below and night to what is on the other side. In fact, the Sun never sets. One who knows thus becomes united with the Sun, assumes its form, and enters its place.“

In fact, both Varuna and Mitra are identified with the Moon, viz. with the waxing and waning Moon, respectively. Moreover, every $16^{\text {th }}$ day of the month (beginning of the waning half of the moon) is dedicated to Iranian Mithra too. There is an obvious congruence between those Iranian and Vedic concepts of Mitra, for the Satapatha Brāhmaṇa II 4.4.18-19 states it categorically: athaitā́vevārrdhamāsaú mitrāvárunau yá evā̄pūryáte sa várunau yò 'paksīyáte sá mitrastấvetām rấtrimubhaú samágachatastád ... tadváa etām rậtrim mitro várune rétah siñcati tád eténa rétasā prájāyate viz. "Mitra and Varuna are the two halves of the moon: that half which is filling in (viz. the waxing one) is Varuna, and that half which is decreasing (viz. the waning one) is Mitra; they both meet during the night (sc. of New Moon) again...In that same night Mitra implants seed in Varuna, and when it (sc. the Moon) wanes, then it (viz. the New Moon) is produced from that seed".

There Varuna is seemingly presented as the female principle (which seems naturally applicable to the Moon, since the moon was considered female among ancient Greeks and Romans, but also by modern Anglo-Saxons - though in Vedic Sanskrit the moon is male!) in opposition to the male principle, impersonated once by Mitra (as above) and another time by god Indra: yónir evá várunah réta indrah viz. "the womb indeed is Varuna, the seed is Indra" (Śatapatha Brāhmana XII 9.1.17). From there Dumézil (1988, p. 178) concluded quite erroneously that Varuna (equated by him with Greek Ouranos) the Sky, and sky viz. Vedic Dyauh being as he argued "after all, constructed grammatically in many Vedic texts as if it were feminine - is that it is Varuna who is endowed with feminine values". This is however, a completely wrong assumption (showing actually his ignorance of the Vedic texts) for the Vedans made themselves perfectly clear on this matter. Śatapatha Brāhmana X 6.2.2-3 states explicitly: sa vai yah sò 'ttàgníreva sáh tásminyatkím cābhyādádhatyāhitaya evà̄sya tấ áhitayo ha vai tā áhutaya ityáacakșate paró 'kṣam paró 'kṣakāmā hi devăh "That eater is the same as this Agni [the Fire viz. Fire-altar]; and whatever they placed in him is his deposit; and these deposits [āhiti] are cryptically called oblations [āhuti], for the gods love the cryptography [viz. cryptic language]." ādityo vá ásya candrámā eváhitayaścandrámasam hy àdityá ādádhatítya dhidevatám "now the eater, undoubtedly, is Áditya the Sun, and his deposits [viz. offerings] are the Moon, for the Moon is placed into the Sun." Thus undoubtedly Varuna is the Sun and not the Moon or the Sky.

For the ancient Vedans were very well aware that the Moon (viz. Soma) has no Light of his own, and that he actually receives it from the Sun (cf. Rig-Veda IX 71.9, IX 76.4, IX 86.32). Accordingly, bhämeva candramasa à-datta "the splendor of the Moon is taken back by the Sun", hence the Sun is styled $\bar{a}$-ditya $<\bar{a}$-datta "the one which takes it [viz. 
the light] back" (Śatapatha Brāhmaṇa XI 8.3.11). From the above it is clear that Varuṇa was conceived as "one who confines (ties, knits, binds)" the light gradually in a way as if knitting or weaving vāsas "a cloth (fabric, garment)" from tantum "thread" (as is actually said of Soma in IX 86.32, and above). For the same reason, Varuna's jammi ("sister, kinswoman" Rig Veda I 123.5) Usas the Dawn is said to make the vayunāni "webs, woven fabric" (Rig Veda I 92.2), just like Varuna to whom belong the Cloth because vāsah syād granthibhir hi vāso vārunam varunyo hi granthih viz. "by reason of its Knots indeed that the Cloth belongs to Varuna, for the Knot (equal = Bond) is sacred to Varuna indeed" (Śatapatha Brāhmaṇa V 2.5.17). Ușas the Dawn too reveals herself gradually from Darkness to full Light as if weaving cloths of Light and puts her embroidered garment on (cf. Rig-Veda I 92.4) like her brother and kinsman Varuna.

\section{Conclusion}

As is demonstrated during the exposition of this treatise the authentic meaning of the Vedic appellative Varuna regardless of context whether natural (material)-concrete or social (ethical)-abstract it conveys always one and the same meaning of "Bond". This further verifies the conclusion that the same appellative in fact is utilized to denote (depending on context) the same principle of "Bond(ing)" underlying various natural phenomena and human social (ethical) affairs likewise. Therefore, it is against Vedic worldview of man and the universe, and is equally erroneous from a Vedic perspective, to advocate Varuna as representing only and exclusively abstract concept such as "Oath, True Speech, Spoken Truth, Verity, Commandment, etc." or merely natural phenomena such as "the Sun, the Moon, the Night, the Sky, the Ocean" etc.

\section{REFERENCES}

\section{Primary Sources: Sanskrit and Vedic}

Aitareya Brāhmaṇa (Sanskrit Text) at http://titus.uni-frankfurt.de/texte/etcs/ind/aind/ved/rv/ab/ab.htm

Aitareya Upanișad (Sanskrit Text) in Radhakrishnan, Sarvepalli. 1953. The Principal Upanisads. George Allen and Unwin Ltd. London.

Atharva-Veda Saṃitā (Sanskrit Text) at http://titus.uni-frankfurt.de/texte/etcs/ind/aind/ved/av/avs/avs.htm

Chāndogya Upaișad (Sanskrit Text) in Radhakrishnan, Sarvepalli. 1953. The Principal Upanisads. George Allen and Unwin Ltd. London.

Aufrecht, Theodor (ed.). 1877. Die Hymnen des Rigveda. Mandala I-VI. A.Marcus, Bonn.

Aufrecht, Theodor (ed.). 1877. Die Hymnen des Rigveda. Mandala VII-X. A.Marcus, Bonn.

Käțaka Saṃhitā (Sanskrit Text) at http://titus.uni-frankfurt.de/texte/etcs/ind/aind/ved/yvs/ks/ks.htm

Das Kaushītaki Brāhmaṇa, 1887. (herg. Bruno Lindner), I Text, Hermann Costenoble, Jena.

Mahābhārata with the Commentary of Nīlakantha. 1929-1936. Shankar Narhar Joshi, Chitrashala Press, Sadashiv Peth, Poona Pune.

Maitrāayañ Saṃhitā (Sanskrit Text) at http://titus.uni-frankfurt.de/texte/etcs/ind/aind/ved/yvs/ms/ms.htm

Maitrī (or Maitrayan̄īya) Upanișad (Sanskrit Text) in Radhakrishnan, Sarvepalli. 1953. The Principal Upanisads. George Allen and Unwin Ltd. London.

Śatapatha Brāhmaṇa (Sanskrit Text) at http://titus.uni-frankfurt.de/texte/etcs/ind/aind/ved/yvw/sbm/sbm.htm

Taittirīya Samhitā (Sanskrit Text) at

Taittirìya Brāhmana (Sanskrit Text) at http://titus.uni-frankfurt.de/texte/etcs/ind/aind/ved/yvs/tb/tb.htm 


\section{Secondary Sources:}

Anghelina, Catalin. 2013. On the Nature of the Vedic Gods, Sino-Platonic Papers, 241.

Anghelina, Catalin. 2014. On the Date of the Aryan Religion, and the Minoan Religion of the Bull, Sino-Platonic Papers, 248.

Bergaigne, Abel. 1878-1883. La religion védique d'après les hymnes du Rig-Veda. Tome I-III. F. Vieweg, Paris.

Brereton, Joel Peter. 1981. The Ṛgvedic Ādityas. American Oriental Series 63. New Haven.

Coomaraswamy, Ananda Kentish 1935. Angels and Titans, An Essay on Vedic Ontology. Journal of the American Oriental Society, Vol. 35, 373-419.

Dumézil, Georges. 1948/1988. Mitra-Varuna: An Essay on Two Indo-European Representations of Sovereignity. Zone Books, New York.

Eichner-Kühn, Ingrid. 1982. Ein Eidbruch im Rgveda, Münchener Studien zur Sprachwissenschaft, 41, München.

Eliade, Mircea 1978. A History of Religious Ideas. Vol. 1. From the Stone Age to the Eleusinian Mysteries. University of Chicago, Chicago.

Fournet, Arnaud 2010. About the Mitanni Aryan Gods. Journal of Indo-European Studies, Vol. 38, No. 1 \& 2, $26-40$.

Gershevitch, Ilya (trans. and ed.). 1959. The Avestan Hymn to Mithra. Cambridge University Press, Cambridge.

Güntert, Hermann. 1923. Der arische Weltkönig und Heilland. Bedeutungsgeschichtliche Untersuchungen zur indoiranischen Religionsgeschichte und Altertumskunde. M. Niemeyer, Halle/Saale.

Hillebrandt, Alfred. 1927/1980. Vedic Mythology. Vol. I. (Translated from the original German edition of 1927, Breslau); Motilal Banarsidas. Delhi.

Hillebrandt, Alfred. 1929/1980. Vedic Mythology. Vol. II. (Translated from the original German edition of 1929, Breslau); Motilal Banarsidas. Delhi.

Hoffmann, Karl. 1969. Materialen zur altindischen Verbum. Zeitschrift für vergleichende Sprachforschung 83. Bd., 2. H. (1969), Vandenhoeck \& Ruprecht, Göttingen, pp. 193-215.

Hopkins, Edward Washburn. 1895. The Religions of India. Ginn and Company, Boston.

Ivankovic, Milorad. 2017. The Vedic Stellar Saga of 3059 BCE. International Journal of Sanskrit Research, New Delhi; 3(6): 81-89.

Ježić, Mislav. 1994. Sûkte Mitri i Varuni ili blagorjeci Miru i Roti, Književna smotra 91, Zagreb, 125-128.

Keith, Arthur Berriedale. 1925. The Religion and Philosophy of the Veda and Upanishads. Harvard Oriental Series, Vol.31, Harvard University Press, Cambridge (Mass).

Kuiper, Franciscus Bernardus Jacobus 1960. The Ancient Aryan Verbal Contest. Indo-Iranian Journal, Leiden, Vol.4, No.4: 217-284.

Kuiper, Franciscus Bernardus Jacobus 1979. Varuna and Vidusaka: On the origin of the Sanskrit Drama. North Holland Publishing Company, Amsterdam.

Lang, Andrew. 1887. Myth, Ritual and Religion. Longmans, Green and Co. London.

Lüders, Heinrich. 1951. Varuṇa I: Varuṇa und die Wasser. Vandenhoeck \& Ruprecht, Göttingen.

Lüders, Heinrich. 1959. Varuṇa II: Varuṇa und das Rta. Vandenhoeck \& Ruprecht, Göttingen.

Macdonell, Arthur Anthony. 1897. Vedic Mythology. Grundriss der Indo-Arischen Philologie und Altertimskunde. Verlag von Karl.J.Trübner, Strassburg. 


\section{THE INNERMOST ENIGMAS OF THE VEDIC LITERATURE}

Mayrhofer, Manfred. 1976. Kurzgefasstes Etymologisches Wörterbuch Des Altindischen: Band 3, Y-h. Nachträge Und Berichtigungen. Indogermanische Bibliothek. 2. Reihe: Wörterbücher. Universitätsverlag Winter GmbH Heidelberg.

Meillet, Antoine. 1907. Le dieu Indo-Iranien Mitra, Journal Asiatique, 10, Paris, 143-159.

Nabarz, Payam. 2005. The Mysteries of Mithras. Inner Traditions, Rochester, Vermont.

Schmidt, Hans-Peter. 2006. Mitra in Old Indian and Mithra in Old Iranian. Encyclopaedia Iranica, New York.

Schmidt, Hans-Peter. 1978. Indo-Iranian Mitra Studies: The State of the Central Problem, in Études Mithriaques, Acta Iranica 17, Leiden, 345-393.

Simson, Georg von. 1997. Zum Ursprung der Götter Mitra und Varuṇa. Indo-Iranian Journal, 40:1-35.

Sutherland, Gail Hinich 1991. The Disguises of the Demon: The Development of the Yaksa in Hinduism and Buddhism. SUNY Press, New York.

Thieme, Paul. 1973. King Varuna. German Scholars on India, Vol.I, The Chowkhamba Sanskrit Series Office, Varanasi, 1973, 333-349.

Usener, Hermann. 1896. Götternamen: Versuch einer Lehre von der Religiösen Begriffsbildung. Verlag von Friedrich Cohen, Bonn.

Witzel, Michael. 1984. Sur le chemin du ciel. Bulletin des Etudes indiennes, 2, 213-279.

Citation: Milorad Ivanković, "The Innermost Enigmas of the Vedic Literature. American Research Journal of English and Literature, vol 6, no. 1, 2020, pp. 1-14.

Copyright (c) 2020 Milorad Ivanković, This is an open access article distributed under the Creative Commons Attribution License, which permits unrestricted use, distribution, and reproduction in any medium, provided the original work is properly cited. 